\title{
Preliminary landslide mapping in Denmark indicates an underestimated geohazard
}

\author{
Kristian Svennevig ${ }^{* 1}$, Gregor Luetzenburg², Marie K. Keiding ${ }^{1}$, Stig Asbjørn Schack Pedersen ${ }^{1}$ \\ ${ }^{1}$ Geological Survey of Denmark and Greenland (GEUS), Copenhagen, Denmark. ${ }^{2}$ Department of Geosciences and Natural Resource Management, \\ University of Copenhagen, Copenhagen, Denmark
}

\begin{abstract}
The process of coastal erosion is well known to the public and decision-makers in Denmark; however, there is little awareness of the risks posed by larger landslides. Only a few scientific studies investigate landslides in Denmark, and as a result, the country is underrepresented in international landslide inventories. Here, we present a systematically produced preliminary landslide inventory based on digital elevation models and high-resolution orthophotos. So far, the preliminary inventory documents 3026 morphological expressions of landslides close to the coast and inland, showing that landslides are more widespread in Denmark than previously recognised. A number of these landslides are near buildings and infrastructure. This paper therefore highlights the potential for geohazardous landslides to occur in Denmark on a national scale and discusses some of the implications. Two of the major questions arising from this study are (1) how to approach potential geohazards in a country with no framework or precedence for landslide hazard and risk management and (2) how landslides and associated risk in Denmark will evolve under a changing climate.
\end{abstract}

\section{Introduction}

Previous studies of landslides in Denmark are limited. Most are mainly field-based investigations of single events or areas with a focus on rockfalls (Table 1), and most of the sparse information is published in Danish 'popular science' magazines. As a result, Denmark may be underrepresented in international landslide inventories (Herrera et al. 2018; Mateos et al. 2020).

Based on the data and methods available at the time, Pedersen et al. (1989) suggested that landslides are not a serious problem in Denmark. Nadim et al. (2008) indicated landslides as the main geohazard in Denmark, but that nonetheless, the country was not seriously affected by them. These studies laid important groundwork by identifying areas prone to slope failure and provided the first insights into process behaviour at selected sites. Nevertheless, their findings also raised the question: 'How abundant are landslides in Denmark, actually?'

With the emergence of nationwide digital elevation models (DEMs), we can start to acquire comprehensive knowledge about surface processes all over

\author{
*Correspondence: ksv@geus.dk \\ Received: 18 June 2020 \\ Accepted: 15 Sept 2020 \\ Published: 09 Nov 2020
}

Keywords: climate change, Denmark, geohazards, landslide inventory, landslides

\section{Abbreviations:}

DEM: Digital Elevation Model

GIS: Geographical Information System DoD: DEM of Difference

InSAR: Interferometric Synthetic Aperture Radar

GEUS Bulletin is an open access, peerreviewed journal published by the Geological Survey of Denmark and Greenland (GEUS). This article is distributed under a CC-BY 4.0 licence, permitting free redistribution, and reproduction for any purpose, even commercial, provided proper citation of the original work. Author(s) retain copyright.

Edited by: Rasmus Bødker Madsen (GEUS, Denmark)

Reviewed by: Kurt H. Kjær (University of Copenhagen, Denmark) and Reginald L. Hermanns (Geological Survey of Norway, Norway)

Funding: See page 6

Competing interests: None declared

Additional files: None provided 
Table 1 Previously published peer-reviewed studies on landslides in Denmark. See Fig. 1 for locations

\begin{tabular}{lll}
\hline Reference & Area & Topic \\
\hline Andersen (1957) & Salten & Geomorphology \\
Hansen (1959) & Salten & Geomorphology \\
Prior (1973) & Røsnæs & Landslides, mudslides \\
Hansen (1975) & Salten & Geomorphology \\
Prior \& Eve (1975) & Røsnæs & Landslides, mudslides \\
Prior (1977) & Røsnæs, Helgenæs and Røjle Klint & Mudslides \\
Pedersen (1987) & Mors & Glaciotectonic complex, landslides \\
Pedersen et al. (1989) & Regional & Landslides \\
Hutchinson (2002) & Møn & Rockfalls \\
Busby et al. (2002) & Møn, Stevns & Rockfalls \\
Pedersen \& Møller (2004) & Møn, Stevns & Rockfalls \\
Pedersen (2005) & Lønstrup Klint & Glaciotectonic complex, landslides \\
Nadim et al. (2008) & Regional & Geohazards \\
Pedersen \& Gravesen (2009) & Møn & Rockfalls \\
Pedersen \& Damholt (2012) & Stevns & Rockfalls \\
Pedersen (2012) & Møn & Rockfalls \\
\hline
\end{tabular}

Table 2 Publicly available data from the Danish Agency for Data Supply and Efficiency used in the landslide mapping

\begin{tabular}{|c|c|c|c|c|c|}
\hline Name & Type & Publication year & Access & Source & Resolution $(\mathrm{cm})$ \\
\hline GEODKORTO2019 & Orthophoto & 2019 & WMS & COWI & 12.5 \\
\hline GEODKORTO2018 & Orthophoto & 2018 & WMS & COWI & 12.5 \\
\hline GEODKORTO2017 & Orthophoto & 2017 & WMS & COWI & 12.5 \\
\hline GEODKORTO2016 & Orthophoto & 2016 & WMS & COWI & 12.5 \\
\hline GEODKORTO2015 & Orthophoto & 2015 & WMS & COWI & 12.5 \\
\hline Denmark's Elevation Model & DEM & (2007) 2015 & WCS & SDFE & (160) 40 \\
\hline DDOland2014 & Orthophoto & 2014 & WMS & COWI & 12 \\
\hline
\end{tabular}

the country. Here, we align Danish landslide research with international landslide research by applying stateof-the-art landslide classifications and methods for landslide inventory mapping. This work is the first step towards a comprehensive mapping of landslides in Denmark. We consider the current landslide mapping to be preliminary, because it is not yet validated and extended with additional information about the mapped slides. In the future, the database will be validated, extended and published in its entirety to address the various scientific questions raised at the end of this paper.

\section{Methods}

The current landslide mapping is based entirely on freely available high-resolution geodata from the Danish Agency for Data Supply and Efficiency (SDFE; Table 2). The primary dataset used is a $40 \mathrm{~cm}$ spatial resolution DEM produced from airborne laser scanning data (SDFE 2020). These data have been acquired since 2007 and are periodically updated. We used the 2015 DEM as it was the latest complete release available when our project began. The DEM is visualised as a multidirectional hillshade model in order to observe morphological appearances of landslides across Denmark. Orthophotos with a $12.5 \mathrm{~cm}$ resolution from multiple years assisted the mapping for visual validation. Generally, spatial coverage is consistent throughout Denmark. In a few small areas, for example, steep or overhanging cliffs on Stevns Klint and Møns Klint, data accuracy is insufficient due to the close to nadir angles of the airborne sensors. In other areas, the model suffers from insufficient data points causing morphologies to be obscured by interpolation. Overall, these minor data gaps do not influence the spatial completeness of the mapped landslide database. In the few cases where landslides have been mapped in these areas, it has been noted in the attribute table.

The mapping workflow is similar to that reported by Svennevig (2019) for mapping landslides in Greenland and a simplified version to that of Slaughter et al. (2017). A landslide was mapped when either a scarp or a displaced unit or both were clearly visible in the multidirectional hillshade model (Fig. 2A). We thus only include landslides with moderate to high confidence, similar to Burns \& Madin (2009) and Slaughter et al. (2017). Moreover, based on the high-quality and detail of the DEM, as well as the support of the observations with the time series of orthophotos (Table 2), we consider all the mapped landslides to be identified with high confidence. We characterised each landslide by its morphological features following the idealised depiction and 
nomenclature of a rotational earthflow from Highland (2004), as well as the commonly used landslide classification of Hungr et al. (2014). In many cases, additional morphological features such as a crown, transverse cracks, main body or foot supported the identification. When the foot was not visible in the hillshade model due to erosion by waves or anthropogenic overprint, the older orthophotos were consulted to identify the landslides morphological expression on the record closest to the event. It should be noted that as the mapping is based on the above described morphological criteria and datasets, it is not suitable for mapping slides with small volumes or faint morphologies such as rockfalls and mudslides. These types are thus expected to be underrepresented in the database.

The mapping itself consists of drawing a polygon with a high number of vertices around an identified landslide, based on the spatial delineation in the high-resolution hillshade model. Landslides with a minimum spatial extend of around $25 \mathrm{~m}^{2}$ were mapped. Two mappers each mapped around half of the landslides in the preliminary database and validated the respective other half. We used QGIS, a free and open source cross-platform geographic information system (GIS) to display the multidirectional hillshade model and the orthophotos, as well as to map the landslides. Every mapped polygon of a landslide was assigned a unique identification number, and the following information was recorded for each ID: shape, proximity to coastline, morphological indication of recent activity, given name (if available), name of the person who mapped the landslide and hazard potential. In a free-text column, we noted additional useful information, including anthropogenic cause/ overprint, type of hazard (e.g. 'house on slide'), validation by historic sources, sign of change in the dataset used and DEM quality.

\section{Preliminary results and discussion}

At the time of publication, the preliminary landslide inventory consists of 3026 distinct landslides in Denmark (Fig. 1). Of these, 2318 are at or near the coast (<300 m) and 708 are more than $300 \mathrm{~m}$ from the coast and considered inland.

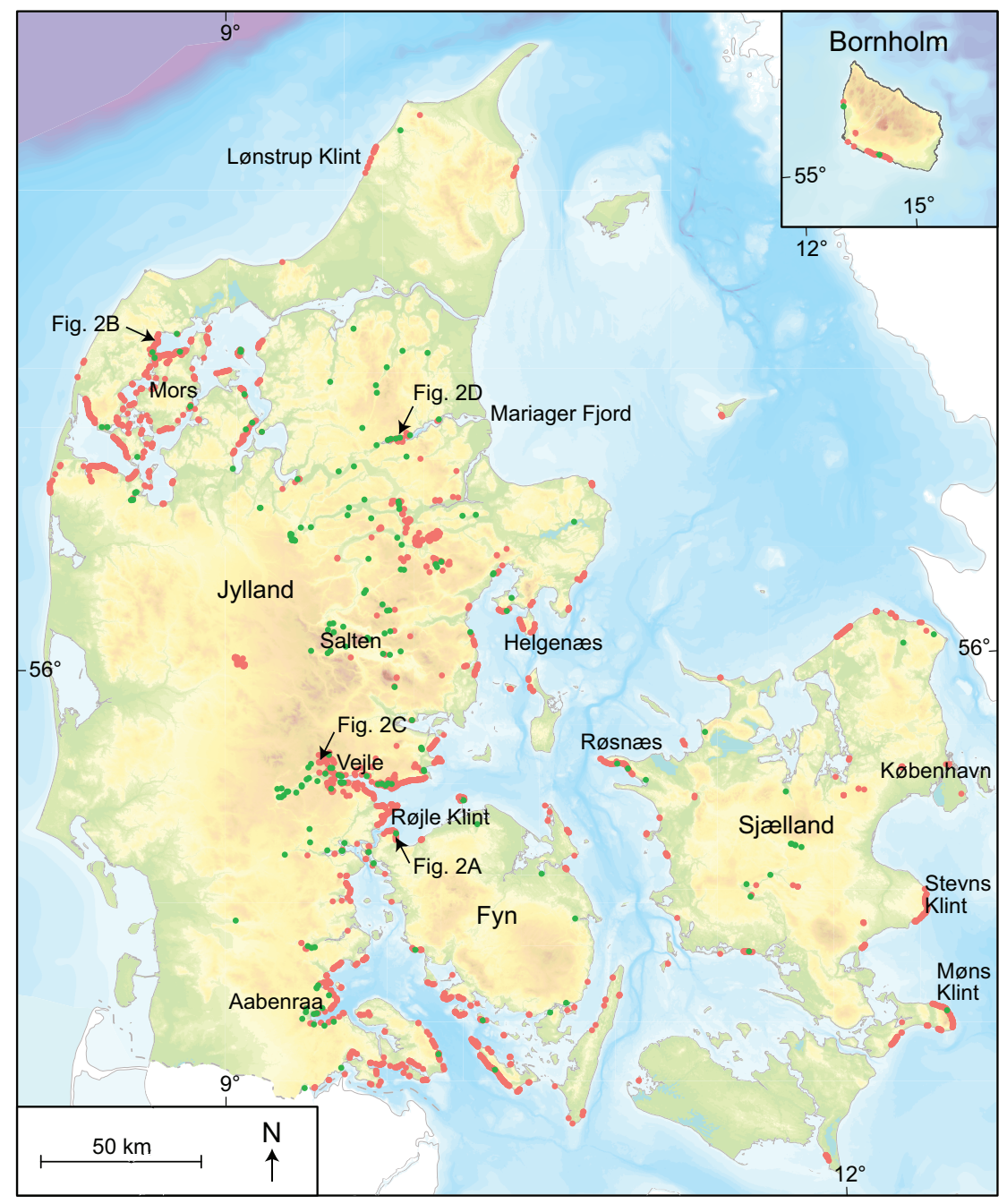

Fig. 1 Mapped landslides in Denmark. Green dots show 172 landforms with overprint of younger processes, such as fluvial incision. Red dots show 2854 landslides that are not modified by other geological processes - some of these show indications of recent activity. Place names mentioned in the text and Table 1 along with positions of panels in Fig. 2 are shown. 

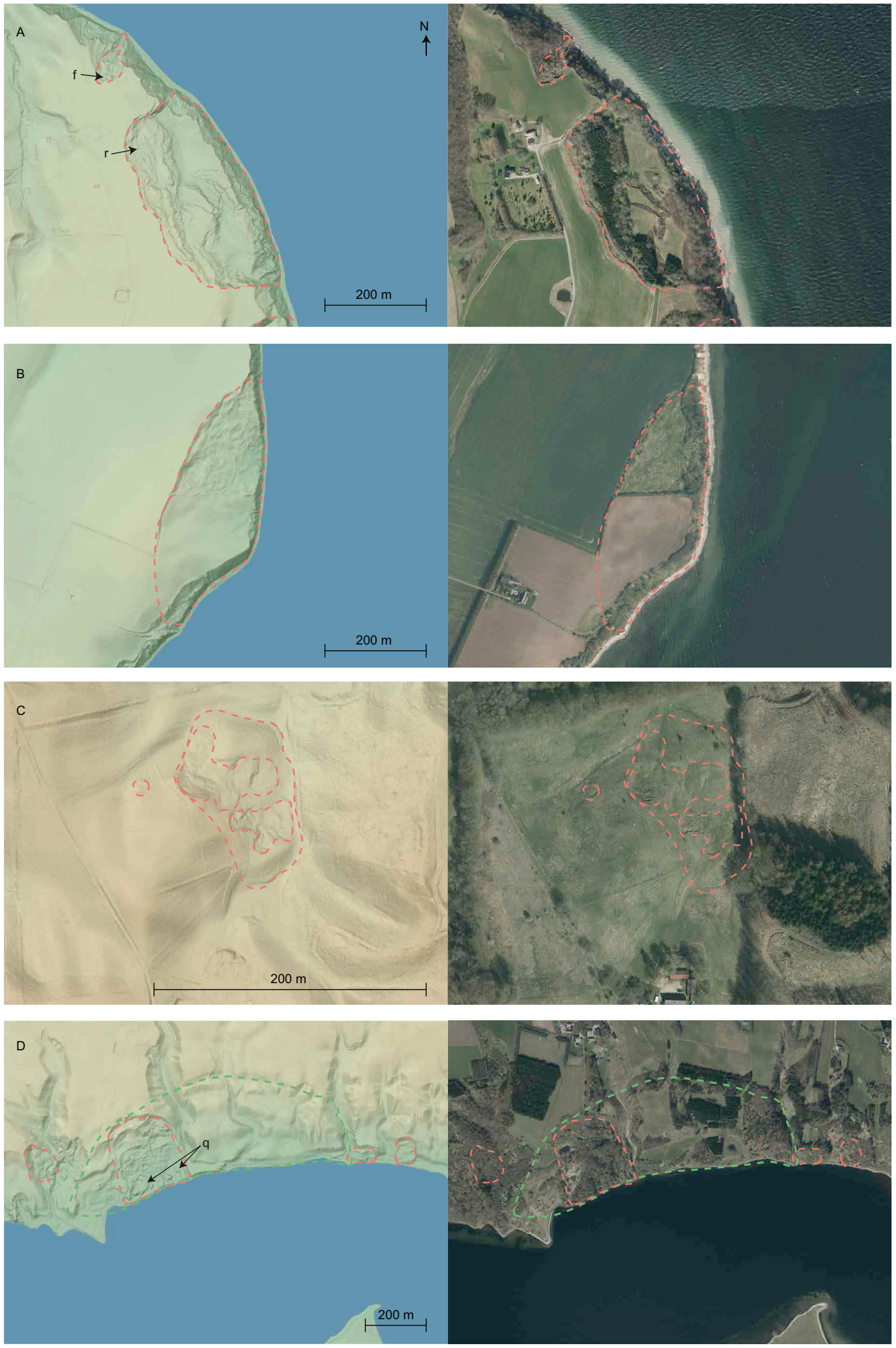

Fig. 2 Four examples of landslides from Denmark in the DEM hillshade (left) and an orthophoto (right). A: Large active rotational landslide (r) and flow (f), east of Røjle Klint, Fyn. B: Large rotational landslide, north of Mors, northern Jylland; the southern part of the landslide is partially concealed by farming activities. The northern uncultivated part of the landslide has clear internal structures, while the southern part is ploughed annually obscuring structures. This landslide would not have been mapped if not for the structures in the northern part. C: Inland landslide near Vejle, Jylland, superimposed by smaller flows. The large landslide is presumably a rotational or translational landslide or a combination. D: Example of a landslide (green) eroded by fluvial incision and a younger landslide (red) in Mariager Fjord, Jylland. Structures in the young landslide are somewhat obscured by quarrying (q), which could have been a triggering factor for the landslide. 
Many of the mapped landslides may record multiple events that overlap in extent. As such, the mapped polygons should be considered areas of past and/or present landslide activity. Some of these may have been successive events, while others are single events of abrupt change. Others may represent areas of continuous slow sliding.

Anthropogenic overprint, such as from cultivation, buildings and infrastructure, is commonly observed on many landslides and can obscure their expression in the DEM. Since farmland covers $56 \%$ of Denmark's surface, the chance that landslide structures are obscured by cultivation and thus not mapped is rather high (Fig. 2B). This is especially the case for shallow slides and inland landslides (Fig. 2C). Quarries can be overprinted by slides, potentially having a triggering effect (Fig. 2D), but old unmapped quarries may also be mistaken for landslides.

A total of 172 landforms, some exceptionally large, fit the morphological criteria for a landslide but have a morphological overprint by younger processes such as fluvial incision (see Fig. 1). These may be interpreted as landslides formed during periglacial or paraglacial phases of landscape development (Fig. 2D). These extraordinary landforms resemble large-scale landforms in Aabenraa, southern Denmark, identified as possible landslides by Lykke-Andersen \& Sørensen (2018) and could have played a hitherto unrecognised role in degrading the Danish landscape in postglacial times, which calls for further investigation.

\section{Outlook}

Since this paper is the first step towards a comprehensive landslide inventory of Denmark, there are several means to extend the work in terms of verification, expansion and application of the database.

\section{Verification and expansion of the database}

The preliminary landslide inventory will be quality controlled for all of Denmark and validated in places by means of field observations and comparison with mentions of landslide events in newspapers and historical archives. Linking hydrological, meteorological, land use and geological datasets to the landslide inventory could provide further information about the preconditioning and driving factors of slope failures in Denmark and elsewhere. This could lead to the first landslide susceptibility map of Denmark.

The current database does not provide any information about the state of activity of the landslides. A valuable add-on will thus be a classification of each landslide as either active, suspended, reactivated, dormant, stabilised or relict sensu Cruden \& Varnes (1996), where possible. This will be achieved by the analysis of Interferometric Synthetic Aperture Radar (InSAR), DEM of Difference (DoD) and multiple generations of orthophotos (Table 2). Sentinel 1 InSAR data from the European Copernicus Satellite mission will be used to calculate the line of sight displacement of slides with natural reflectors on a 6-day repeat cycle since 2015, enabling an unprecedented temporal resolution for the monitoring of current surface movements. DoDs will be produced from the three nationwide DEMs recorded at 4-8-year intervals since 2006 . They can also be used to quantify three-dimensional morphological changes and rates of erosion. The DoD coverage can be extended up to 90 years back in time on a local scale by implementing DEMs from several sets of historical aerial stereo photos, providing valuable information on the longer-term evolution of landslide activity in Denmark.

\section{Application}

The high temporal and spatial resolution of the underlying datasets available for the mapping of landslides in Denmark has several potential applications. Landslide activities across the globe are expected to increase in the coming decades as a result of climate change (IPCC 2014; Gariano \& Guzzetti 2016). In Denmark, climate change is expected to cause an increase in frequency and magnitude of heavy precipitation events, storm surges and sea-level rise, which may have an accelerating effect on landslide activity. It is crucial to understand how these processes affect landslides and develop a toolset to predict future changes and quantify how these will impact society. Combining local and regional climate models with the above-mentioned susceptibility map would allow us to quantify the effects of climate change on landslides in Denmark now and in the near future.

The database could also be applied to quantify the threat landslides and may pose to Danish society. During the mapping exercise, several infrastructure objects, buildings and agricultural lands were noted as located on or near landslides. Integrating DoD and InSAR data into the database, as mentioned earlier, along with overlay analysis of GIS datasets of infrastructure, buildings and land use will help to identify potentially hazardous landslides. These data analyses should be followed up by detailed site-specific field work to form the basis for informed decisions on mitigation measures.

This work can further lay the foundation for the development of a legislative framework dealing with the consequences of landslides in Denmark and integrate a landslide hazard and risk mitigation evaluation in climate adaptation plans. This is an area, in which Denmark has previously been identified as falling behind other EU countries (Mateos et al. 2020). 


\section{Acknowledgements}

We thank professor Aart Kroon and assistant professor Anders A. Bjørk for their valuable input on the project. SDFE are thanked for their support and Joanna Balasis-Levinsen (SDFE) for giving us early access to InSAR data. We kindly thank professors Kurt H. Kjær and Reginald Hermanns for constructive reviews that helped to improve the final version of the paper.

\section{Additional information}

Funding statement

GL has received funding from the European Union's Horizon 2020 research and innovation programme under the Marie Skłodowska-Curie grant agreement No 801199, which funded his hours on the study.

\section{Authors' contributions}

KSV: conceptualization. KSV, GL: data curation, formal analysis and writing (original draft, review and editing). MKK: formal analysis and writing (review and editing). SASP: writing (original draft).

\section{References}

Andersen, S.A. 1957: De jyske kildedale og deres problemer. Meddelelser Dansk Geologisk Forening 13, 438-440.

Burns, W.J. \& Madin, I.P. 2009: Protocol for inventory mapping of landslide deposits from light detectlon and ranging (lidar) imagery. Oregon Department of Geology and Mineral Industries Special Paper 42, $30 \mathrm{p}$.

Busby, J.P., Gourry, J.C., Senfaute, G., Pedersen, S.A.S. \& Mortimore, R. 2002: Can we predict coastal cliff failure with remote, indirect measurements? In: Jakeways, J. \& McInnes, R. (eds): Instability, planning and management, 203-208. London: Thomas Telford. https://doi. org/10.1680/ipamssstgmp.31326

Cruden, D.M. \& Varnes, D.J. 1996: Landslides types and processes. In: Turner, A.K. \& Schuster, R.L. (eds): Landslides: investigation and mitigation. Transportation Research Board Special Report 247, 36-75.

Gariano, S.L. \& Guzzetti, F. 2016: Landslides in a changing climate. Earth-Science Reviews 162, 227-252. https://doi.org/10.1016/j.earscirev. 2016.08.011

Hansen, K., 1959. Saltenprofilet. Meddelelser Dansk Geologisk Forening 14, 1-7.

Hansen, K., 1975. The Salten Valley A geomorphological analysis. Dansk Geologisk Forenings Årskrift for 1974, 5-23.

Herrera, G. et al. 2018: Landslide databases in the Geological Surveys of Europe. Landslides 15, 359-379. https://doi.org/10.1007/ s10346-017-0902-z

Highland, L., 2004: Landslide types and processes. Fact Sheet 2004-3072. Reston: US Geological Survey. https://doi.org/10.3133/fs20043072

Hungr, O., Leroueil, S. \& Picarelli, L. 2014: The Varnes classification of landslide types, an update. Landslides 11, 167-194. https://doi. org/10.1007/s10346-013-0436-y

Hutchinson, J.N. 2002: Chalk flows from the coastal cliffs of northwest Europe. Reviews in Engineering Geology 15, 257-302. https://doi. org/10.1130/reg15-p257
IPCC. 2014. Climate Change 2014: Synthesis Report. Contribution of Working Groups I, II and III to the Fifth Assessment Report of the Intergovernmental Panel on Climate Change. Geneva, Switzerland: IPCC, $151 \mathrm{pp}$.

Lykke-Andersen, H. \& Sørensen, P.B. 2018: Aabenraa-modellen: et landskab formet af jordskred. Geoviden 3, 16-19.

Mateos, R.M. et al. 2020: Integration of landslide hazard into urban planning across Europe. Landscape and Urban Planning 196, 103740. https://doi.org/10.1016/j.landurbplan.2019.103740

Nadim, F., Pedersen, S.A.S., Schmidt-Thomé, P., Sigmundsson, F. \& Engdahl, M. 2008: Natural hazards in Nordic countries. Episodes 31, 176-184. https://doi.org/10.18814/epiiugs/2008/v31i1/024

Pedersen, S.A.S. 1987: Comparative studies of gravity tectonics in Quaternary sediments and sedimentary rocks related to fold belts. Geological Society (London) Special Publications 29, 165-179. https://doi. org/10.1144/gsl.sp.1987.029.01.14

Pedersen, S.A.S. 2005: Structural analysis of the Rubjerg Knude Glaciotectonic Complex, Vendsyssel, northern Denmark, Geological Survey of Denmark and Greenland Bulletin 8, 192 pp. https://doi.org/10.34194/ geusb.v8.4848

Pedersen, S.A.S. 2012: Rockfalls at chalk cliffs in northern Europe. In: Eberhardt, E. et al. (eds): Landslides and engineered slopes: protecting society through improved understanding, 1127-1132. London: Taylor \& Francis Group.

Pedersen, S.A.S. \& Damholt, T. 2012: Cliff collapse at Stevns Klint, southeast Denmark. Geological Survey of Denmark and Greenland Bulletin 26, 33-36. https://doi.org/10.34194/geusb.v26.4745

Pedersen, S.A.S., Foged, N. \& Frederiksen, J. 1989: Extent and economic significance of landslides in Denmark, Faroe Islands and Greenland. In: Brabb, H. (ed): Landslides: extent and economic significance, 153-156. Rotterdam: Balkema.

Pedersen, S.A.S. \& Gravesen, P. 2009: Structural development of Maglevandsfald: a key to understanding the glaciotectonic architecture of Møns Klint, SE Denmark. Geological Survey of Denmark and Greenland Bulletin 17, 29-32. https://doi.org/10.34194/geusb.v17.5007

Pedersen, S.A.S. \& Møller, I. 2004: Prediction and risk evaluation of chalk cliff collapse: the PROTECT project. Geological Survey of Denmark and Greenland Bulletin 4, 89-92. https://doi.org/10.34194/geusb.v4.4793

Prior, D.B. 1973: Coastal landslides and swelling clays at Røsnæs, Denmark. Danish Journal of Geography 72, 45-48. https://doi. org/10.1080/00167223.1973.10649024

Prior, D.B. 1977: Coastal mudslide morphology and processes on eocene clays in Denmark. Danish Journal of Geography 76, 14-33. https://doi. org/10.1080/00167223.1977.10649071

Prior, D.B. \& Eve, R.B. 1975: Coastal landslide morphology at Røsnæs, Denmark. Danish Journal of Geography 74, 12-20. https://doi. org/10.1080/00167223.1975.10649043

SDFE. 2020: Denmark's Elevation Model, Styrelsen for Dataforsyning og Effektivisering, https://sdfe.dk/hent-data/danmarks-hoejdemodel/

Slaughter, S.L., Burns, W.J., Mickelson, K.A., Jacobacci, K.E., Biel, A., Contreras, T.A. \& Washington, L.E.G. 2017: Protocol for landslide inventory mapping from lidar data in Washington State. Washington Geological Survey Bulletin 82, 1-27.

Svennevig, K. 2019: Preliminary landslide mapping in Greenland. Geological Survey of Denmark and Greenland Bulletin 43, e2019430207. https://doi.org/10.34194/geusb-201943-02-07 